\title{
Australian Journal of

\section{Effect of different sources of organic matter added to the substrate on physiological parameters of clonal plants of conilon coffee}

\author{
Waylson Zancanella Quartezani ${ }^{1 *}$, Ramon Amaro de Sales ${ }^{3}$, Sávio da Silva Berilli ${ }^{2}$, Talita Aparecida \\ Pletsch ${ }^{1}$, Weverton Pereira Rodrigues ${ }^{4}$, Eliemar Campostrini ${ }^{4}$, Wallace de Paula Bernado ${ }^{4}$, Evandro Chaves \\ de Oliveira ${ }^{2}$, Leonardo Raasch Hell ${ }^{1}$, Euzileni Mantoanelli ${ }^{1}$
}

${ }^{1}$ Instituto Federal de Educação, Ciência e Tecnologia do Espírito Santo / Campus Montanha, Rodovia ES 130, km 01, Bairro Palhinha, CEP: 29890-000, Montanha, ES, Brasil

${ }^{2}$ Instituto Federal de Educação, Ciência e Tecnologia do Espírito Santo / Campus Itapina, Rodovia BR 259, km 70, Zona Rural, CEP: 29700-970, Colatina, ES, Brasil

${ }^{3}$ Universidade Federal do Espírito Santo, Centro de Ciências Agrárias e Engenharias, Alegre, Brasil

${ }^{4}$ Universidade Estadual do Norte Fluminense. Campos dos Goytacazes, Rio de Janeiro, Brasil

*Corresponding author: waylson.quartezani@ifes.edu.br

\begin{abstract}
Organic matter is a fundamental component of a substrate. However, different organic matter sources can provide different physiological responses from seedlings as a result of different types and concentrations of humic substances, which influence the functioning of the plant and the structuring of the soil. The objective of this work was to quantify photosynthetic pigments, gas exchange, and secondary metabolite indices in the abaxial and adaxial parts of leaves of Conilon coffee clonal plantlets grow $n$ in different sources of organic materials. The experiment was arranged in a randomized block design with five treatments and five replications. The treatments consisted of different sources of organic matter added to the substrate: $85 \%$ soil $+15 \%$ urban waste compost; $85 \%$ soil $+15 \%$ mature cattle manure; $85 \%$ soil $+15 \%$ dairy residue; $85 \%$ soil $+15 \%$ tannery sludge; and a Control: $100 \%$ soil, without addition of organic material. The contents of chlorophylls $a, b$, and total, carotenoids, and their ratios were analyzed by destructive methods. Indirect measurements of nitrogen and chlorophyll (SPAD) were performed by non-destructive methods. Fluorescence indices of flavonoids, anthocyanins, total chlorophyll, and nitrogen balance were estimated using a Multiplex ${ }^{\circledR}$ sensor. The substrate added with dairy residue provided the highest chlorophyll a production in the adaxial part, which was confirmed by the SPAD index. Tannery sludge provided the highest production of flavonoids. The comparison between the two forms of evaluation showed that the abaxial part of the leaf had greater sensitivity and that the Multiplex ${ }^{\circledR}$ sensor showed higher sensitivity for detection of indices. No changes were found in plant photosynthesis. However, greater stress was detected in the treatment with tannery sludge.
\end{abstract}

Keywords: Coffea Canephora; nutrition; photosynthesis; propagation; secondary metabolism.

Introduction

Conilon coffee is of great relevance for the socioeconomic development of Brazil, particularly for the state of Espírito Santo, because it is the basis of its economy. The crop is mainly grownby small and medium scale farmers, providing jobs and financial stability for these families. Resende et al. (2009) and Ronchi et al. (2015) point out that the Brazilian coffee industry is one of the most important activities in the agroindustrial sector, and the country is currently the largest producer in the world.

In Brazil, there is a large demand for seedlings due to the increase in planted area and adaptation to new planting systems. Because coffee is a perennial crop, it is necessary to plan all its stages, especially those linked to implantation and formation of the crop (Dardengo et al., 2013). The planting of high vigor seedlings is fundamental for a good development of the crop, ensure a fast growth of the plants, with a larger stand, and the ability to express the productive potential to the maximum, beyond reduce the costs with the replanting operation (Alves and Guimarães, 2010; Quartezani et al., 2018). It is the most used vegetative propagation method and assures the uniformity of the coffee crop.

The technology for the production of coffee seedlings has been changed to improve quality of plantlets. These changes mainly relate to the type of container, substrate, time and management of fertilization and irrigation (Henrique et al., 2011). For the production of coffee seedlings, the literature recommends substrates made up of subsoil earth, decomposed organic material, and chemical fertilizers (Ferrão et al., 2012).

Organic matter is the major factor influencing the quality of the substrate. It improves the substrate physical conditions, increases the soil microbiota, changes the colloidal complex 
with superficial charges (Bezerra et al., 2006) and, thus, improves both the cation exchange capacity and nutrient retention of the soil (Silva et al., 2014). These characteristics vary with the origin of the organic material used. It is known that humic substances in decomposed organic matter can accelerate growth by behaving similarly to auxin (Baldotto and Baldotto, 2013).

The production of seedlings with good shoot development is important because the leaves contain chloroplasts, which are responsible for photosynthesis. In addition, the synthesis of secondary metabolites such as anthocyanins and flavonoids, to a greater extent, has the main function of protecting the plants against oxidizing agents and serving as indicative of environmental stress (Lopes et al., 2010; Silva et al., 2015; Berilli et al., 2016).

Therefore, the investigation of the effect of different organic residues on the physiological processes of the coffee tree, including pigments in the antenna complex, secondary metabolites, and gas exchange will provide important information to be analyzed, since several external factors affect the primary and secondary metabolism of plants (Biasi et al., 2009).

Technology advancements have provided the market with new devices that can indirectly measure chlorophyll indices or chlorophyll contents, secondary metabolites, and gas exchange. For instance, the SPAD index has been much used in the indirect measurement of chlorophylls and plant nitrogen status (Torres Neto et al., 2005; Amarante et al., 2009). Dualex (Goulas et al., 2004) detects polyphenols in the leaf, and infrared gas analyzers measure gas exchange (Silva, 2001). Along with these methods, Multiplex also measures indices using plant tissue fluorescence by multiple sources of light excitation (Rossato et al., 2012), resulting in indices associated with the concentration of secondary metabolites, nitrogen, and chlorophyll.

The use of organic residues from different sources in the production of seedlings can reduce pollution in addition to being a low cost organic compound (Berilli et al., 2016). Therefore, the objective of this work was to evaluate the effects of different sources of organic matter added to the substrate of Conilon coffee seedlings on photosynthetic pigments, gas exchange, and secondary metabolite indices at leaf-scale.

\section{Results and discussion}

\section{Effect of the substrate on the photosynthetic pigments of} leaves

The results of the present study showed that there was difference in most of the evaluated characteristics, suggesting that the different sources of organic matter cause different effects on the physiology of Conilon coffee seedlings. No difference was found in carotenoid production among the treatments and no influence of the source of organic matter was detected (Table 2).

As Table 2 shows, there was difference in the SPAD index among the treatments with $15 \%$ of organic matter, and the treatment with dairy residue stood out among the other sources. The lowest value was recorded for the treatment with tannery sludge, with a mean SPAD index of 25.7, lower than the treatment with dairy residue by more than $60 \%$. Tannery sludge has total chromium content higher than the other sources of organic matter (Table 2). This may have caused a reduction in the chlorophyll content, besides, chromium is considered toxic to plants at high concentrations and may cause chlorosis in young leaves (Santos, 2015).

The chlorophyll $a$ content in all the substrates with organic matter was higher than the T-Control, except T-Tannery, which was equal to the control treatment. The treatment with dairy residue presented $34 \%$ more chlorophyll $a$ than the treatment without any source of organic matter in the substrate.

A possible explanation for the difference in chlorophyll $a$ may be that organic matter from dairy residue has $20 \%$ more nitrogen and $26 \% \mathrm{~K}_{2} \mathrm{O}$ in its composition (Table 2), which may increase the content of this pigment. Experiments conducted by Viana and Kiehl (2010) with different doses of nitrogen and potassium showed that the combination of these elements increased the content of chlorophylls in wheat.

The analysis of chlorophyll $b$ showed that the substrates containing dairy residue and cattle manure had a higher amount of this pigment than the other treatments (Table 2). This shows an increase in light-harvesting complexes, increasing solar energy capturing efficiency and the transport of electrons. However, no difference was found between chlorophyll $a / b$ ratios, indicating that this increase in chlorophyll $b$ had no influence on chlorophyll $a$ production. There was also a lower total chlorophyll production in T-Control and T-Tannery caused by the reduction previously observed in chlorophyll $a$ and $b$ contents in these treatments. This may be associated with oxidative stress resulting in degradation of chlorophyll molecules, especially in the T-Tannery treatments due to high chromium concentrations (Santos, 2015).

\section{Effect of the substrate on the characteristics obtained by the Multiplex ${ }^{\circledR}$ fluorometer}

Table 3 shows the data obtained by the Multiplex sensor, noting that the results were expressed differently, according to the reading methodology. In this experiment, a significant difference was found for the flavonoid index only when the adaxial part of the leaf was evaluated. The highest flavonoid index was recorded for the substrate with tannery sludge, showing its influence on the production of this secondary compound.

These results corroborate those of Berilli et al. (2016) in Conilon coffee seedlings, but using the entire plant. These authors tested different doses of tannery sludge and found a higher production of flavonoids in the plants that received higher doses of tannery sludge in the substrate. They found no difference in the chlorophyll index, which agrees with the findings of this study for the adaxial and abaxial leaf parts.

Table 3 shows differences in the indices of flavonoid, anthocyanin, and nitrogen balance for the leaf adaxial part, and the best result for the nitrogen balance, that is, the highest values, were found in the T-Dairy. This indicates a greater amount of nitrogen available in the leaves of seedlings grown in the dairy residue, which is in agreement with the higher SPAD indices and total chlorophyll content in the T-Dairy, since nitrogen is a very important nutrient for chlorophyll synthesis (Taiz and Zeiger, 2009). Positive correlations between SPAD indices and nitrogen content 
Table 1. Characteristics of the organic materials added to the substrate for seedlings.

\begin{tabular}{|c|c|c|c|c|c|}
\hline Parameter & Unit & Tannery sludge & Cattle manure & Dairy residue & $\begin{array}{c}\text { Urban waste } \\
\text { compost }\end{array}$ \\
\hline Moisture at $60-65^{\circ} \mathrm{C}$ & $\%$ & 8.89 & 8.52 & 5.39 & 7.58 \\
\hline $\mathrm{pH}$ in $\mathrm{CaCl}_{2}$ & - & 7.65 & 6.78 & 6.96 & 7.30 \\
\hline Density & $\mathrm{g} / \mathrm{cm}^{3}$ & 0.6 & 0.6 & 0.75 & 0.6 \\
\hline TOM & $\%$ & 23.72 & 46.33 & 33.17 & 50.52 \\
\hline C & $\%$ & 12.98 & 20.19 & 17.31 & 23.08 \\
\hline $\mathrm{C} / \mathrm{N}$ & - & $7 / 1$ & $10 / 1$ & $9 / 1$ & $9 / 1$ \\
\hline $\mathrm{N}$ & $\mathrm{g} / \mathrm{dm}^{3}$ & 17.40 & 21.00 & 20.20 & 24.90 \\
\hline$P$ & $\mathrm{~g} / \mathrm{dm}^{3}$ & 7.21 & 11.93 & 4.54 & 5.63 \\
\hline K & $\mathrm{g} / \mathrm{dm}^{3}$ & 2.49 & 7.47 & 5.64 & 15.02 \\
\hline $\mathrm{Ca}$ & $\mathrm{g} / \mathrm{dm}^{3}$ & 230.20 & 21.80 & 111.10 & 40.70 \\
\hline $\mathrm{Mg}$ & $\mathrm{g} / \mathrm{dm}^{3}$ & 17.50 & 5.40 & 16.90 & 5.10 \\
\hline$S$ & $\mathrm{~g} / \mathrm{dm}^{3}$ & 83.30 & 4.50 & 2.00 & 5.20 \\
\hline $\mathrm{Fe}$ & $\mathrm{g} / \mathrm{dm}^{3}$ & 2.50 & 0.40 & 7.50 & 8.70 \\
\hline $\mathrm{Na}$ & $\mathrm{g} / \mathrm{dm}^{3}$ & 4.80 & 3.70 & 2.40 & 6.30 \\
\hline $\mathrm{Zn}$ & $\mathrm{mg} / \mathrm{dm}^{3}$ & 71.00 & 357.60 & 141.60 & 119.20 \\
\hline $\mathrm{Cu}$ & $\mathrm{mg} / \mathrm{dm}^{3}$ & 12.50 & 135.00 & 17.00 & 32.50 \\
\hline $\mathrm{Mn}$ & $\mathrm{mg} / \mathrm{dm}^{3}$ & 102.20 & 553.40 & 158.50 & 160.00 \\
\hline B & $\mathrm{mg} / \mathrm{dm}^{3}$ & 409.20 & 16.10 & 17.20 & 39.50 \\
\hline $\mathrm{Cr}$ & $\mathrm{mg} / \mathrm{dm}^{3}$ & 60.00 & 20.00 & 19.50 & 36.08 \\
\hline
\end{tabular}

TOM: Total Organic Matter; Results on dry matter basis (mass/mass); C/N: Carbon/nitrogen ratio; C: Organic carbon; N: Nitrogen; P: Phosphorus; K: Potassium; Ca: Calcium; Mg: Magnesium; S: Sulfur; Fe: Iron; Na: Sodium; Zn: Zinc; Cu: Copper; Mn: Manganese; B: Boron; Cr: Total chromium.

Table 2. Mean of photosynthetic pigment contents and SPAD index in leaves of Conilon coffee seedlings grown in substrates added with different organic matter sources at 120 days of age.

\begin{tabular}{lccccccc}
\hline Treatment & SPAD & \multicolumn{1}{c}{ Chl $a$} & Chl $b$ & Chl t & Car & Chl $a / b$ & Chl t/Car \\
\cline { 3 - 8 } & & & \multicolumn{7}{c}{ mmol.m } \\
\hline $\mathrm{T}_{0}$-Control & $30.8 \mathrm{c}$ & $172.6 \mathrm{~b}$ & $32.6 \mathrm{~b}$ & $205.2 \mathrm{~b}$ & $34.1 \mathrm{a}$ & $5.3 \mathrm{a}$ & $6.2 \mathrm{~b}$ \\
$\mathrm{~T}_{1}$-Compost & $35.2 \mathrm{~b}$ & $196.4 \mathrm{a}$ & $37.9 \mathrm{~b}$ & $234.3 \mathrm{a}$ & $33.6 \mathrm{a}$ & $5.3 \mathrm{a}$ & $6.9 \mathrm{~b}$ \\
$\mathrm{~T}_{2}$-Manure & $35.5 \mathrm{~b}$ & $218.7 \mathrm{a}$ & $46.1 \mathrm{a}$ & $264.8 \mathrm{a}$ & $35.5 \mathrm{a}$ & $4.8 \mathrm{a}$ & $7.4 \mathrm{a}$ \\
$\mathrm{T}_{3}$-Dairy & $43.6 \mathrm{a}$ & $232.9 \mathrm{a}$ & $47.7 \mathrm{a}$ & $280.6 \mathrm{a}$ & $35.7 \mathrm{a}$ & $4.9 \mathrm{a}$ & $7.9 \mathrm{a}$ \\
$\mathrm{T}_{4}$-Tannery & $25.7 \mathrm{c}$ & $147.7 \mathrm{~b}$ & $30.5 \mathrm{~b}$ & $178.3 \mathrm{a}$ & $27.7 \mathrm{a}$ & $4.9 \mathrm{a}$ & $6.5 \mathrm{~b}$ \\
\hline $\mathrm{GM}$ & 34.4 & 193.7 & 38.9 & 232.6 & 33.3 & 5.1 & 6.9 \\
\hline $\mathrm{CV}(\%)$ & 15.3 & 17.2 & 22.4 & 17.3 & 17.9 & 15.9 & 11.5
\end{tabular}

GM: General Mean; Means followed by different letters in the column are significantly different by the Scott-Knott's test at $1 \%$ probability level. SPAD: indirect measurement of chlorophyll and nitrogen balance; $\mathrm{Chl} a$ : chlorophyll $a$; Chl $b$ : chlorophyll $b$; Chl t: total chlorophyll; Car: carotenoids; Chl $a / b$ : chlorophyll $a$ and $b$ ratio; $\mathrm{Chl}$ t/Car: total chlorophyll and carotenoids ratio.

Table 3. Mean indices of flavonoids, anthocyanin, chlorophyll, and nitrogen balance obtained by the Multiplex sensor from leaves of Conilon coffee seedlings grown in substrates added with different organic matter sources at 120 days.

\begin{tabular}{|c|c|c|c|c|c|c|c|}
\hline $\begin{array}{l}\text { Treatment } \\
\text { Adaxial leaf }\end{array}$ & FLAV & SFR-G & SFR-R & NBI-G & $\mathrm{NBI}-\mathrm{R}$ & ANTH-RG & ANTH-RB \\
\hline $\mathrm{T}_{0}$-Control & $0.49 \mathrm{~b}$ & $1.95 \mathrm{a}$ & $1.83 \mathrm{a}$ & $0.79 \mathrm{~b}$ & $0.74 \mathrm{~b}$ & $0.03 \mathrm{~b}$ & $-0.53 a$ \\
\hline $\mathrm{T}_{1}$-Compost & $0.32 \mathrm{c}$ & $1.99 \mathrm{a}$ & $1.85 \mathrm{a}$ & $0.86 \mathrm{~b}$ & $0.80 \mathrm{~b}$ & $0.06 a$ & $-0.51 a$ \\
\hline $\mathrm{T}_{2}$-Manure & $0.51 b$ & $2.27 \mathrm{a}$ & $2.13 a$ & $0.94 \mathrm{~b}$ & $0.85 b$ & $0.02 \mathrm{c}$ & $-0.54 a$ \\
\hline $\mathrm{T}_{3}$-Dairy & $0.28 \mathrm{c}$ & $2.14 \mathrm{a}$ & $2.01 \mathrm{a}$ & $1.15 \mathrm{a}$ & $1.04 \mathrm{a}$ & $0.03 b$ & $-0.53 a$ \\
\hline $\mathrm{T}_{4}$-Tannery & $0.63 \mathrm{a}$ & $2.05 \mathrm{a}$ & $1.92 \mathrm{a}$ & $0.55 \mathrm{c}$ & $0.48 \mathrm{c}$ & $0.02 \mathrm{c}$ & $-0.52 a$ \\
\hline GM & 0.44 & 2.08 & 1.95 & 0.86 & 0.78 & 0.03 & 0.53 \\
\hline $\mathrm{CV}(\%)$ & 17.28 & 17.73 & 15.36 & 20.88 & 18.93 & 17.67 & 6.68 \\
\hline $\begin{array}{l}\text { Treatment } \\
\text { Abaxial leaf }\end{array}$ & FLAV & SFR-G & SFR-R & NBI-G & NBI-R & ANTH-RG & ANTH-RB \\
\hline $\mathrm{T}_{0}$-Control & $0.04 \mathrm{a}$ & $1.06 \mathrm{a}$ & $1.00 \mathrm{a}$ & $1.05 \mathrm{a}$ & $0.88 \mathrm{a}$ & $0.06 \mathrm{~b}$ & $-0.64 b$ \\
\hline $\mathrm{T}_{1}$-Compost & $0.01 \mathrm{~b}$ & $1.03 \mathrm{a}$ & $0.98 a$ & $1.16 \mathrm{a}$ & $0.94 \mathrm{a}$ & $0.08 \mathrm{a}$ & $-0.63 a$ \\
\hline $\mathrm{T}_{2}$-Manure & 0.05 a & $1.09 \mathrm{a}$ & $1.03 \mathrm{a}$ & $1.07 \mathrm{a}$ & $0.91 \mathrm{a}$ & $0.05 b$ & $-0.65 b$ \\
\hline $\mathrm{T}_{3}$-Dairy & $-0.01 b$ & $1.04 \mathrm{a}$ & 0.99 a & $1.15 \mathrm{a}$ & 0.97 a & $0.07 \mathrm{~b}$ & $-0.66 b$ \\
\hline $\mathrm{T}_{4}$-Tannery & $0.03 \mathrm{a}$ & $1.05 \mathrm{a}$ & $0.99 \mathrm{a}$ & $1.13 \mathrm{a}$ & $0.93 \mathrm{a}$ & $0.06 \mathrm{~b}$ & $-0.65 b$ \\
\hline GM & 0.02 & 1.05 & 1.00 & 1.12 & 0.93 & 0.06 & 0.64 \\
\hline CV(\%) & 18.69 & 12.90 & 11.63 & 16.11 & 16.01 & 18.81 & 3.53 \\
\hline
\end{tabular}

Means followed by different letters in the column are significantly different by the Scott-Knott's test at 1\% probability level. Flavonoids (FLAV), anthocyanin (ANT-RG and ANT-RB), chlorophyll (SFR-G and SFR-R), and nitrogen balance (NBI-G and NBI-R). 
Table 4. Simple correlation coefficients $(r)$ for physiological characteristics obtained by chlorophyll extraction and SPAD and Multiplex sensors from leaves of Conilon coffee seedlings grown in substrates added with different organic matter.

\begin{tabular}{|c|c|c|c|c|c|}
\hline & $\begin{array}{l}\text { NBI_G } \\
\text { adaxial }\end{array}$ & NBI_R adaxial & $\begin{array}{l}\text { NBI_G } \\
\text { abaxial }\end{array}$ & NBI_R abaxial & SPAD \\
\hline $\mathrm{Chl} a$ & $0.687^{* *}$ & $0.591 * *$ & $-0.077^{n / s}$ & $-0.056^{n / s}$ & $0.760 * *$ \\
\hline $\mathrm{Chl} b$ & $0.671 * *$ & $0.498^{*}$ & $-0.254^{n / s}$ & $-0.198^{n / s}$ & $0.660 * *$ \\
\hline Chl t & $0.697^{* *}$ & $0.584 * *$ & $-0.114^{n / s}$ & $-0.085^{n / s}$ & $0.751 * *$ \\
\hline Car & $0.533^{* *}$ & $0.411^{*}$ & $-0.346^{n / s}$ & $-0.351^{n / s}$ & $0.784 * *$ \\
\hline
\end{tabular}

** $1 \%$ probability and * $5 \%$ probability by the $t$ test; $\mathrm{n} / \mathrm{s}$ : non-significant; Chl $a$ : chlorophyll $a$; Chl $b$ : chlorophyll $b$; Chl t: total chlorophyll; Car: carotenoids; SPAD: indirect measure of chlorophyll; nitrogen balance (NBI-G and NBI-R).

Table 5. Means of net photosynthetic rate (A), stomatal conductance (gs), transpiration rate (E), vapor pressure deficit between leaf and air (VPD leaf-air), and leaf temperature (CTleaf) in Conilon coffee seedlings grown in substrates added with different organic matter.

\begin{tabular}{lccccc}
\hline Treatment & $A$ & $g s$ & $E$ & VPD $_{\text {leaf-air }}$ & CTleaf \\
\hline $\mathrm{T}_{0}$-Control & $7.76 \mathrm{a}$ & $0.21 \mathrm{a}$ & $2.84 \mathrm{a}$ & $1.44 \mathrm{a}$ & $28.75 \mathrm{a}$ \\
$\mathrm{T}_{1}$-Compost & $7.79 \mathrm{a}$ & $0.28 \mathrm{a}$ & $3.47 \mathrm{a}$ & $1.38 \mathrm{a}$ & $28.65 \mathrm{a}$ \\
$\mathrm{T}_{2}$-Manure & $8.22 \mathrm{a}$ & $0.25 \mathrm{a}$ & $3.44 \mathrm{a}$ & $1.52 \mathrm{a}$ & $28.76 \mathrm{a}$ \\
$\mathrm{T}_{3}$-Dairy & $8.59 \mathrm{a}$ & $0.33 \mathrm{a}$ & $4.45 \mathrm{a}$ & $1.39 \mathrm{a}$ & $28.79 \mathrm{a}$ \\
$\mathrm{T}_{4}$-Tannery & $7.87 \mathrm{a}$ & $0.30 \mathrm{a}$ & $4.03 \mathrm{a}$ & $1.20 \mathrm{a}$ & $28.76 \mathrm{a}$ \\
\hline $\mathrm{GM}$ & 8.05 & 0.28 & 3.65 & 1.39 & 28.74 \\
\hline $\mathrm{CV}(\%)$ & 21.74 & 22.82 & 18.04 & 10.15 & 0.71 \\
\hline
\end{tabular}

Means followed by different letters in the column are significantly different by the Scott-Knott's test at $1 \%$ probability level.

Table 6. Means of initial fluorescence (Fo), maximum quantum yield of FS II (Fv/Fm), maximum fluorescence (Tfm), effective quantum yield (Fv/Fo), and performance index (PI) in Conilon coffee seedlings grown in substrates added with different organic matter.

\begin{tabular}{lccccc}
\hline Treatment & Fo & Fv/Fm & Tfm & Fv/Fo & PI \\
\hline $\mathrm{T}_{0}$-Control & $6279.8 \mathrm{a}$ & $0.79 \mathrm{a}$ & $196.6 \mathrm{a}$ & $3.96 \mathrm{a}$ & $2.71 \mathrm{a}$ \\
$\mathrm{T}_{1}$-Compost & $6425.0 \mathrm{a}$ & $0.81 \mathrm{a}$ & $182.5 \mathrm{a}$ & $4.36 \mathrm{a}$ & $2.29 \mathrm{a}$ \\
$\mathrm{T}_{2}$-Manure & $6744.0 \mathrm{a}$ & $0.79 \mathrm{a}$ & $190.5 \mathrm{a}$ & $4.04 \mathrm{a}$ & $2.08 \mathrm{a}$ \\
$\mathrm{T}_{3}$-Dairy & $6316.8 \mathrm{a}$ & $0.81 \mathrm{a}$ & $186.7 \mathrm{a}$ & $4.40 \mathrm{a}$ & $2.56 \mathrm{a}$ \\
$\mathrm{T}_{4}$-Tannery & $5895.8 \mathrm{a}$ & $0.79 \mathrm{a}$ & $146.0 \mathrm{a}$ & $3.87 \mathrm{a}$ & $0.94 \mathrm{~b}$ \\
\hline $\mathrm{GM}$ & 6332.28 & 0.80 & 180.37 & 4.13 & 2.22 \\
\hline $\mathrm{CV}(\%)$ & 8.76 & 3.09 & 14.02 & 13.04 & 31.67 \\
\hline
\end{tabular}

Means followed by different letters in the column are significantly different by the Scott-Knott's test at 1\% probability level.

were reported for $C$. canephora by Torres Neto et al. (2005). It is apparent that lowest values of the NBI index, in both the green light and red light excitation, were recorded for the treatment with tannery sludge (Table 3 ). It is likely that the tannery sludge has caused a greater stress to the plants because of its higher chromium content (Table 1). Peteinatos et al. (2016) evaluated NBI-G and NBI-R in wheat subjected to stress by both water and competition of invasive plants and found that the plants under stress showed lower nitrogen indices. The Multiplex indices from the abaxial part of Conilon coffee leaves (Table 3 ) clearly show a difference in the anthocyanin index (ANTH-RG), and we found that the plants grown in substrate added with urban compost had higher production of this secondary metabolite along with the ANTH-RG of the adaxial part. According to Einbond et al. (2004), anthocyanins, among their several functions, protect plant tissues through the stages of their life cycle. However, the treatment with urban compost showed very low flavonoid indices in the abaxial and adaxial parts, which suggests that the increase occurred only in the production of anthocyanins. This may be associated with the higher amount of potassium in this organic matter (Table 1) and the fact that potassium plays a role in the synthesis of carbohydrates and proteins, in respiration, and enzymatic activities (Trevisan et al., 2006). Noting that carbohydrates can be used in the production of anthocyanins. So far, there has been a lack of studies investigating the influence of organic matter on the production of anthocyanins in plant leaves. The reason for this is that anthocyanins belong to a subclass of flavonoids, the polyphenols (Schiozer and Barata, 2013), and are usually associated with the color of fruits and flowers. In this way, several studies have used the Multiplex sensor to measure fruit maturation such as in plum (Salama et al., 2015), grape (Ghozlen et al., 2010, Agati et al., 2013), and apple (Van Beers et al., 2014). However, as mentioned by Lopes et al., (2007), anthocyanins have functions not only related to reproductive organs, but also as antioxidants, protection against the effects of sunlight, defense mechanism, and biological function. Therefore, it is very important to know the processes related to the synthesis and degradation of this pigment in the leaves. The analyses of both the adaxial and abaxial parts of the leaves using the Multiplex sensor showed that the highest means are obtained almost always from the adaxial part, with a production of flavonoids much higher than the abaxial part. This is perfectly explained by the fact that adaxial parts are exposed to a higher light incidence and consequently need greater protection against daily photoinhibition. 


\section{Correlation for the physiological characteristics}

Table 4 shows the correlations between pigments obtained by chlorophyll extraction and with the SPAD indices and the nitrogen balance from the adaxial and abaxial leaf parts. Positive significance was found for all characteristics of the adaxial part, which suggests that high contents of chlorophylls $a, b$, total, and carotenoids caused an increase in both the SPAD and nitrogen balance indices, as reported by Torres-Netto et al. (2005). On the other hand, the abaxial part of the leaf showed no correlation with the nitrogen balance, showing that in the plants this index is mainly generated in the adaxial part of the leaf.

The SPAD index was sensitive to the chlorophyll content of the plants, along with the carotenoids, showing a positive relationship between the increase in chlorophyll and the increase in carotenoids. Carotenoids, although lacking the green color, are accessory pigments that play an essential role in photoprotection (Streit et al., 2005; Taiz and Zeiger, 2009). However, the total chlorophyll content by the Multiplex sensor showed no correlation with any of the parts evaluated.

\section{Effect of organic matter on gas exchange and chlorophyll fluorescence a}

Although differences existed for the treatments relative to the main leaf pigments, there were no significant differences for the gas exchange data (Table 5) and the fluorescence parameters (Table 6), except for PI. $A$ mean was around 8 $\mu \mathrm{mol} \mathrm{CO} \mathrm{C}^{-2} \mathrm{~s}^{-1}$, whereas the means of gs and $\mathrm{E}$ were 0.28 mol $\mathrm{H}_{2} \mathrm{O} \mathrm{m}^{-2} \mathrm{~s}^{-1}$ and $3.65 \mathrm{mmol} \mathrm{H}_{2} \mathrm{O} \mathrm{m} \mathrm{s}^{-1}$, respectively. Additionally, $\mathrm{VPD}_{\text {leaf-air }}$ and leaf temperature means were $1.39 \mathrm{kPa}$ and $28.74{ }^{\circ} \mathrm{C}$, respectively. These values are within the ranges observed in coffee plants in field conditions (Rodrigues et al., 2016).

Although the $A$ means are within the range normally found for coffee plants (DaMatta and Ramalho, 2006), even in field conditions (Rodrigues et al., 2016), there was a trend of higher means in T-Manure and T-Dairy following the values of the nitrogen balance (Table 3). This is because, high doses of nitrogen strengthens the enzymatic antioxidant system of coffee plants (Ramalho et al., 1998).

The responses of the parameters gas exchange (Table 5) and fluorescence (Table 6) are probably caused by the robust enzymatic antioxidant system of the coffee plants, as well as other protective molecules besides those studied in this study, which can compensate the differences between some pigments (Ramalho et al., 2014; Martins et al., 2016).

Together, these molecules can protect the photosystems by suppression of reactive oxygen species and, thus, avoid membrane lipid peroxidation in chloroplasts (Ramalho et al., 2014). This reflected in the fluorescence means, especially in the Fv/Fm means (Table 6), which were above 0.78 . It shows the optimal efficiency of the photosynthetic system II (Ramalho et al., 1998; Rodrigues et al., 2016), as well as the means of Fo, Tfm, Fv/Fo, and PI (Rodrigues et al., 2016).

$\mathrm{PI}$ is considered a very sensitive parameter and is widely used to detect environmental stress (Strasser et al., 2004). It shows that the T-Tannery induced a greater stress response in the plants, which was probably caused by the chromium present in this material, thus reducing its photochemical metabolism. This indicates that the presence of toxic elements to plants even at not very high concentrations may result in changes associated with damage to the photosynthetic apparatus, and consequently to the plant performance index.

Overall, the results of this study indicate the possibility of using alternative sources of organic matter for the production of coffee seedlings, without changing physiological parameters that are crucial for a good establishment of the crop, besides contributing to the reduction of organic residues.

\section{Materials and methods}

\section{Study site}

The study was carried out at the Federal Institute of Education, Science and Technology of Espírito Santo Campus Itapina, located in the municipality of Colatina $\left(19^{\circ} 32^{\prime} 22^{\prime \prime} \mathrm{S} 40^{\circ} 37^{\prime} 50^{\prime \prime} \mathrm{W}\right.$; $71 \mathrm{~m}$ altitude). This experiment was conducted in a nursery, with seedlings of Coffea canephora (Conilon-Clone 02) in a randomized complete block design. Five treatments were tested according to different organic sources added to the substrate, arranged in five blocks, and each experimental plot consisted of 10 plants.

\section{Experimental design}

The treatments were as follows: $\mathrm{T}_{0}$-Control: $100 \%$ soil; $\mathrm{T}_{1}$ Compost: $85 \%$ soil $+15 \%$ urban waste compost; $T_{2}-$ Manure: $85 \%$ soil $+15 \%$ mature cattle manure; $\mathrm{T}_{3}$-Dairy: $85 \%$ soil + $15 \%$ dairy residue; $\mathrm{T}_{4}$-Tannery: $85 \%$ soil $+15 \%$ tannery sludge. All treatments received 10 grams of limestone and 10 grams of single superphosphate (FSS) per liter of substrate. The soil used for the substrate mixtures is classified as a Red Dystrophic Latosol (EMBRAPA, 2013), with the following chemical characteristics: $\mathrm{pH}$ : 5.3 ; phosphorus: $4.0 \mathrm{mg} / \mathrm{dm}^{3}$; potassium: $52.0 \mathrm{mg} / \mathrm{dm}^{3}$; remaining phosphorus: $20 \mathrm{mg} / \mathrm{ml}$; calcium: $11.6 \mathrm{mmol}_{\mathrm{c}} / \mathrm{dm}^{3}$; magnesium $9.3 \mathrm{mmol}_{\mathrm{c}} / \mathrm{dm}^{3}$; aluminum $0.5 \mathrm{mmol}_{\mathrm{c}} / \mathrm{dm}^{3}$; potential acidity $(\mathrm{H}+\mathrm{Al}) 14.0$ mmol $\mathrm{c}_{\mathrm{d}} \mathrm{dm}^{3}$; organic matter: $1,5 \mathrm{~g} / \mathrm{dm}^{3}$; base sum (B.S.): $22.2 \mathrm{mmol}_{\mathrm{c}} / \mathrm{dm}^{3}$; $\mathrm{CEC}$ at $\mathrm{pH} 7(\mathrm{~T}): 36.2 \mathrm{mmol}_{\mathrm{c}} / \mathrm{dm}^{3}$; Effective CEC (t): $22.7 \mathrm{mmol}_{\mathrm{c}} / \mathrm{dm}^{3}$; aluminum saturation $(\mathrm{m}): 2.2 \%$; and base saturation: $61.4 \%$.

The chemical parameters of the organic residues evaluated are described in Table 1 . The chemical analyzes of each characteristic of the organic residues were performed according to the methodology recommended by the Ministry of Agriculture (MAPA, 2013).

The seedlings were planted in in $8 \times 18 \mathrm{~cm}$ plastic bags manually filled with previously mixed materials in the treatment proportions, observing the compaction of the parts. The substrates were under continuous irrigation in the seedling nursery for 30 days before the planting of the cuttings.

The cuttings were selected from the shoots of clone 02 of the variety Conilon Vitória Incaper 8142. At the time of planting, the main stem was cut about $3 \mathrm{~cm}$ below and $1 \mathrm{~cm}$ above the petiole, the secondary stems were cut at $1 \mathrm{~cm}$ of the main stem, as well as $2 \beta$ of the leaf area. The seedlings received cultural treatments throughout the experimental period as recommended by Ferrão et al. (2012).

\section{Evaluated characteristics}

At the end of the experiment, 121 days after cutting, the seedlings reached the planting size and the evaluations were 
performed using a colorimeter (SPAD 502 - Minolta) and a fluorometer (Multiplex - Force A). The indirect evaluation of the $\mathrm{N}$ nutritional status was performed with a Soil Plant Analysis Development Chlorophyll Meter (SPAD-502 Minolta) taking the mean of three points on the second fully expanded leaf, in the field, between 9:00 and 11:00 a.m. Two analyses were performed with the Multiplex fluorometer to estimate indices of different compounds, including nitrogen balance (NBI-G and NBI-R), total chlorophyll (SFR-G and SFR-R), anthocyanin (ANT-RG and ANT-RB), and flavonoids (FLAV). The analyses were performed in both the adaxial part and the abaxial part of the leaf, using the same leaf that was previously evaluated for the SPAD index, at the soil laboratory of IFES-Itapina. The two analyses performed with the Multiplex sensor were used to test whether there is a difference in the indices produced by the plants, in order to determine which part better expresses the results.

Next, chlorophyll was extracted from the leaf evaluated by both the SPAD and Multiplex sensors. Chlorophyll and carotenoid contents were extracted with the organic solvent dimethylsulfoxide (DMSO), according to the methodology of Hiscox and Israelstam (1979) based on spectrophotometer readings at the wavelengths $663 \mathrm{~nm}, 645 \mathrm{~nm}$, and $480 \mathrm{~nm}$. Net photosynthetic rate $(A)$, stomatal conductance $(g s)$, transpiration rate $(E)$, vapor pressure deficit between leaf and air ( $\left.\mathrm{VPD}_{\text {leaf-air }}\right)$, and leaf temperature (CTleaf) were measured between 08:00 and 10:00 a.m. on fully developed leaves of the second pair using an infrared gas analyzer (model LI-6400, Li-COR, Lincoln, Nebraska, USA). The fluorescence of chlorophyll $a$ was measured in the same leaves used for gas exchange analysis, on the same day and time. For this analysis, the leaf part was adapted to dark for about 30 minutes using clips (Hansatech) so that all reaction centers were in the "open" state (oxidized Qa) (Bolhár Nordenkampf et al., 1989). Initial fluorescence (Fo), quantum efficiency of photosystem II (Fv/Fm), maximum efficiency of the photosynthetic process in photosystem II (Fv/Fo), and photosynthetic index (PI) were obtained by fluorescence kinetics.

\section{Statistical analysis}

The data were examined by analysis of variance and the Scott-Knott's test at $1 \%$ probability level. Simple correlation tests between variables were performed. All statistical analyses were performed using the open source program $R$ (R Core Team 2016).

\section{Conclusion}

The photosynthetic pigments extracted showed significant difference among the different treatments, except for carotenoid production and chlorophyll $\mathrm{a}$ and $\mathrm{b}$ ratio.

The results of the Multiplex ${ }^{\circledast}$ sensor showed that the adaxial part had greater sensitivity for the characteristics obtained by the fluorometer and, for both methods of evaluation, the highest flavonoid index production was found in the treatment with tannery sludge.

The correlations between the pigments extracted from leaves and the SPAD sensor were significant, however, the Multiplex ${ }^{\circledast}$ sensor showed significance only for the nitrogen balance in the adaxial part of the leaf.

No significant differences were found among the treatments for the parameters gas exchange and chlorophyll a fluorescence.

T-Manure and T-Dairy were found as the best organic sources for the production of Conilon coffee seedlings.

\section{Acknowledgements}

The authors thank the Federal Institute of Espirito Santo Ifes and the National Council for Scientific and Technological Development - CNPQ.

\section{References}

Agati G, D'Onofrio C, Ducci E, Cuzzola A, Remorini D, Tuccio L, Lazzini F, Mattii G (2013) Potential of a multiparametric optical sensor for determining in situ the maturity components of red and white vitis vinifera wine grapes. J Agric Food Chem. 61(50): 12211-12218.

Alves JD, Guimarães RJ (2010) Sintomas de desordens fisiológicas em cafeeiro, In: Guimarães RJ, Mendes ANG, Baliza DP Semiologia do cafeeiro: sintomas de desordens nutricionais, fitossanitárias e fisiológicas. Lavras. 169-215.

Amarante CVTD, Zanardi O, Miqueloto A, Steffens CA, Erhart J, Almeida JAD (2009) Quantificação da área e do teor de clorofilas em folhas de plantas jovens de videira 'cabernet sauvignon'mediante métodos não destrutivos. Rev Bras Frutic. 31(3): 680-686.

Baldotto MA, Baldotto LEB (2013) Gladiolus development in response to bulb treatment with different concentrations of humic acids. Rev Ceres. 60(1): 138-142.

Berilli SS, Zooca AAF, Rembinski J, Salla PHH, Almeida JD, Martineli L (2016) Influência do acúmulo de cromo nos índices de compostos secundários em mudas de café conilon. Coffee Science. 11(4): 512-520.

Bezerra FB, Oliveira MACL, Perez DV, Andrade AG, Meneguelli NA (2006) Lodo de esgoto em revegetação de área degradada. Pesq agropec bras. 41(3): 469-476.

Biasi LA, Machado EM, Kowalski AP, Signor D, Alves MA, Lima Fl, Deschamps C, Côcco L, Scheer AP (2009) Adubação orgânica na produção, rendimento e composição do óleo essencial da alfavaca quimiotipo eugenol. Hortic bras. 27(1): 35-39.

Bolhár Nordenkampf HR, Long SP, Baker NR, Öquist G, Schreiber U, Lechner EG (1989) Chlorophyll fluorescence as a probe of the photosynthetic competence of leaves in the field: a review of current instrumentation. Funct Ecol. 3(4): 497-514.

DaMatta FM, Ramalho JDC (2006) Impacts of drought and temperature stress on coffee physiology and production: a review. Braz. J. Plant Physiol. 18(1): 55-81.

Dardengo MCJD, Sousa EF, Reis EF, Gravina GDA, (2013) Growth and quality of conilon coffee seedlings produced at different containers and shading levels. Coffee Science. 8(4): 500-509.

EMBRAPA (2013). Sistema brasileiro de classificação de Solos. 3. ed. Rio de Janeiro: Embrapa Solos.

Einbond LS, Reynertson KA, Luo XD, Basile MJ, Kennelly EJ (2004) Anthocyanin antioxidants from edible fruits. Food chemistry. 84(1): 23-28.

Goulas Y, Cerovic ZG, Cartelat A, Moya I (2004) Dualex: a new instrument for field measurements of epidermal ultraviolet absorbance by chlorophyll fluorescence. Appl Opt. 43(23): 4488-4496.

Ferrão RG, Fonseca AFA, Ferrão MAG, Verdin Filho AC, Volpi OS, Muner LH, Lani JÁ, Prezotti LC, Ventura JA, Martins DS, Mauri AL, Marques EMG, Zucateli F (2012) Café conilon: 
técnicas de produção com variedades clonais, 4 ed Revisada e ampliada, Vitória, ES: Incaper (Incaper: Circular Técnica, 03-I). 74.

Ghozlen NB, Moise N, Latouche G, Martinon V, Mercier L, Besancon E, Cerovic Z (2010) Assessment of grapevine maturity using a new portable sensor: Non destructive quantification of anthocyanins. J Int Sci Vigne Vin. 44: 1-8.

Hiscox JD, Israelstam GF (1979) A method for the extraction of chlorophyll from leaf tissue without maceration. Can J Bot. 57(12): 1332-1334.

Henrique PC, Alves JD, Deuner S, Goulart PFP, Livramento DE (2011) Aspectos fisiológicos do desenvolvimento de mudas de café cultivadas sob telas de diferentes colorações. Pesq agropec bras. 46(5): 458-465.

Lopes RM, Oliveira TD, Nagem TJ, Pinto AS (2010) Flavonóides. Biotecnologia cienc desenvolv. 3(14): 18-22.

Lopes T, Xavier M, Quadri MG, Quadri M (2007) Antocianinas: uma breve revisão das características estruturais e da estabilidade. Rev Bras Agrociênc. 13(3): 291-297.

Ministério da Agricultura Pesca e Abastecimento. Secretaria de Defesa Agropecuária-MAPA (2013). Manual de métodos analíticos oficiais para fertilizantes e corretivos. Brasília, DF: Ministério da Agricultura Pesca e Abastecimento. Disponível

em: http://sistemasweb.agricultura.gov.br/arquivosislegis/anex os/arquivos/1204363.PDF. Acesso em: 05 Jul. 2017.

Martins $M Q$, Rodrigues WP, Fortunato $A S$, Leitão $A E$, Rodrigues AP, Pais IP, Martins LD, Silva MJ, Reboredo FH, Partelli FL, Campostrini E, Tomaz MA, Scotti-Campos P, Ribeiro-Barros Al, Lidon FC, DaMatta FM, Ramalho JC (2016) Protective response mechanisms to heat stress in interaction with high $\left[\mathrm{CO}_{2}\right]$ conditions in Coffea spp. Front Plant Sci. 7: 947.

Peteinatos GG, Korsaeth A, Berge TW, Gerhards R (2016) Using optical sensors to identify water deprivation, nitrogen shortage, weed presence and fungal infection in wheat. Agriculture. 6(2): 24.

Quartezani WZ, Sales RA, Pletsch TA, Berilli SS, Nascimento AL, Hell LR, Mantoanelli E, Berilli APCG, Silva RTP, Toso R (2018) Conilon plant growth response to sources of organic matter. Afr J Agric Res. 13(4): 181-188.

Ramalho JC, Campos PS, Teixeira M, Nunes M A (1998) Nitrogen dependent changes in antioxidant system and in fatty acid composition of chloroplast membranes from Coffea arabica L. plants submitted to high irradiance. Plant Science. 135(2): 115-124.

Ramalho JC, DaMatta FM, Rodrigues AP, Scotti-Campos $P$, Pais I, Santos PB, Partelli FL, Ribeiro A, Lidon FC, Leitão AE (2014) Cold impact and acclimation response of Coffea spp. plants. Theor Exp Plant Physiol. 26(1): 5-18.

R Core Team (2016) R: A language and environment for statistical computing. R Foundation for Statistical Computing, Vienna, Austria. URL: https://www.Rproject.org/.

Resende O, Arcanjo RV, Siqueira VC, Rodrigues S (2009) Modelagem matemática para a secagem de clones de café (Coffea canephora Pierre) em terreiro de concreto. Acta Sci Agron. 31(2): 189-196.
Rodrigues WP, Vieria HD, Campostrini E, Figueiredo FAMMA, Ferraz TM, Partelli FL, Ramalho JC (2016). Physiological aspects, growth and yield of Coffea spp. in areas of high altitude. AJCS. 10(5): 666-674.

Ronchi CP, Araújo FCD, Almeida WLD, Silva MAAD, Magalhães CEDO, Oliveira LBD, Drumond LCD (2015) Ecophysiological responses of coffee plants subjected to water deficit to narrow blossom period in the Cerrado in the state of Minas Gerais, Brazil. Pesq agropec bras. 50(1): 24-32.

Rossato OB, Sanchez PA, Guerra SPS, Crusciol CAC (2012) Sensores de reflectância e fluorescência na avaliação de teores de nitrogênio, produção de biomassa e produtividade do algodoeiro. Pesq agropec bras. 47(8): 1133-1141.

Salama A, Neumüller M, Treutter D (2015) Preliminary study on non-destructive assessment of european plum (Prunus Domestica L.) maturity. Acta Hortic. 1099(28): 257-262.

Santos JLA (2015) Valores de prevenção para fitotoxidez por cromo em solos de Minas Gerais. UFLA, 97 p.: il. Dissertação (Ciências do Solo), Universidade Federal de Lavras.

Schiozer AL, Barata LES (2013) Estabilidade de corantes e pigmentos de origem vegetal. Rev Fitos. 3(2): 6-24.

Silva MM, Maldonado H, Bressan-Smith RE, Coelho JFD, Avila E (2001) Diferenças varietais nas características fotossintéticas de Pennisetum purpureum Schum. Rev bras Zootec. 30(6): 1975-1983.

Silva JPS, Nascimento CWA, Silva DJ, Cunha KPV, Biondi CM (2014) Alterações na fertilidade dos solos e teores foliares de nutrientes em cultivos de mangueira no Vale do São Francisco. Brazilian Journal of Agricultural Sciences. 9(1): 42-48.

Silva RL, Martins LV, Calou LBF, Deus MSM, Ferreira PMP, Peron AP (2015) Flavonóides: constituição química, ações medicinais e potencial tóxico. Acta toxicol argent. 23(1): 36-43.

Strasser RJ, Srivastava A, Tsimilli-Michael M (2004) Analysis of the chlorophyll a fluorescence transient. In: Papageorgiou G, Govindjee (eds.) Chlorophyll fluorescence: a signature of photosynthesis. Advances in photosynthesis and respiration. Netherlands. Kluwer Academic Publishers. 19: 321-362.

Streit NM, Canterle LP, Canto MW, Hecktheuer LHH (2005) As clorofilas. Ciência Rural. 35(3): 748-755.

Taiz L, Zeiger E (2009) Fisiologia Vegetal. $4^{\mathrm{a}}$ ed. Artmed, Porto Alegre, 820p.

Torres Netto A, Campostrini, E, Oliveira JG, Smith REB (2005) Photosynthetic pigments, nitrogen, chlorophyll a fluorescence and SPAD-502 readings in coffee leaves. Sci Hortic. 104 (2): 199-209.

Trevisan R, Herter FG, Coutinho EF, Gonçalves ED, Silveira CAP, Freire CJS (2006) Uso de poda verde, plásticos refletivos, antitranspirante e potássio na produção de pêssegos. Pesq agropec bras. 41(10): 1485-1490.

Van Beers R, Gutiérrez LL, Schenk A, Nicolaï B, Kayacan E, Saeys W (2014) Optical measurement techniques for the ripeness determination of Braeburn apples. Proc Inter Con Agr Eng. C0200: 1-7.

Viana EM, Kiehl JDC (2010) Doses de nitrogênio e potássio no crescimento do trigo. Bragantia. 69(4): 975-982. 